\title{
Digestion of proteoglycans in porcine pancreatic elastase-induced emphysema in rats
}

\author{
C.H.A. van de Lest, E.M.M. Versteeg, J.H. Veerkamp, T.H. van Kuppevelt
}

\begin{abstract}
Digestion of proteoglycans in porcine pancreatic elastase-induced emphysema in rats. C.H.A. van de Lest, E.M.M. Versteeg, J.H.Veerkamp, T.H. van Kuppevelt. @ERS Journals Ltd 1995.

ABSTRACT: Pulmonary emphysema was induced in rats by a single intratracheal instillation of pancreatic elastase. The short-term effects of elastase instillation on basement membrane components were evaluated using immunohistochemical and biochemical methods.

Lung alveoli showed a decrease in heparan sulphate proteoglycan content (especially of its heparan sulphate chains) $3 \mathrm{~h}$ to 7 days after induction. Type IV collagen, laminin and fibronectin were not affected. The glycosaminoglycan content of the lung was decreased during the first 3 days after induction, while the glycosaminoglycan concentration in urine was increased during the first $\mathbf{4}$ days by an increase of heparan sulphate and dermatan sulphate. The increase in urinary glycosaminoglycan content was positively correlated with the extent of emphysema developed after 40 days.

We conclude that proteoglycans are target molecules for elastase, and may be involved in the pathogenesis of emphysema.

Eur Respir J., 1995, 8, 238-245.
\end{abstract}

The connective tissue of the lung parenchyma plays an important role in the functioning of the respiratory system. Alterations in the connective tissue skeleton are believed to be important in several chronic lung diseases, such as emphysema and fibrosis [1,2]. Major components of lung extracellular matrix are elastin, collagen and proteoglycans (PGs). PGs consist of a core protein, to which one or more glycosaminoglycan $(\mathrm{GAG})$ chains are covalently attached. GAGs are polysaccharides which are strongly negatively-charged due to an abundance of carboxylic and/or sulphate groups. In the alveolar wall, two types of PGs are predominantly present: decorin and perlecan. Decorin is a small dermatan sulphate (DS) proteoglycan which is associated with collagen fibrils [3-6], and perlecan is a heparan sulphate proteoglycan (HSPG) present in basement membranes [6-9].

The predominant theory on the pathogenesis of emphysema is the protease/antiprotease concept [10-12]. This concept emanates from a relative excess of proteases (elastases), due to an increase of proteases and/or a decrease of protease inhibitors. An excess of proteases leads to the degradation of the connective tissue skeleton and ultimately to emphysema. One has almost exclusively focused on elastin as the target molecule for proteases, in part because the most studied animal model for emphysema is elastase-induced emphysema. Elastase, however, is also capable of degrading a number of other proteins, including PGs, fibronectin and some types of collagen in vitro $[13,14]$. Digestion of PGs may be of particular importance, since: 1) PGs are involved in fib- rillogenesis of collagen and elastin, and can modulate their mechanical characteristics [3, 4]; 2) PGs interact with and modulate a number of molecules, including growth factors and extracellular matrix molecules [1521]; and 3) GAGs can act as powerful protease inhibitors, e.g. for leucocyte elastase and cathepsin G [22-24]. In addition, the close association of PGs with structural elements in the alveolar wall (e.g. basement membranes, collagen fibrils and elastin fibres) indicates a protective role $[6,25-28]$.

In this respect, we studied the effects of an emphysemainducing dose of pancreatic elastase in rats on perlecan (the core protein as well as the heparan sulphate (HS) side-chains) and on other extracellular matrix components of the alveolar wall by immunohistochemical and biochemical methods. Additionally, we investigated the excretion of GAG into the urine following elastase treatment.

\section{Material and methods}

1,9-Dimethylmethylene blue ( $80 \%$ pure) was purchased from Aldrich Chemical Co., Bornem, Belgium; Universal Gel/8 1\% agarose gels from Ciba-Corning $\mathrm{GmbH}$, Fernwald, Germany; Aquamount from BDH Ltd, Poole UK; halothane from Apharmo, Arnhem, The Netherlands; pentobarbitol (Narcovet) from ICI-Farma, Rotterdam, The Netherlands; diethylaminoethyl (DEAE)-Sepharose Fast Flow from Pharmacia, Uppsala, Sweden; Azure A, 
Tween-20, whale cartilage chondroitin 4-sulphate, bovine kidney HS, porcine pancreatic elastase, bovine serum albumin (BSA), fluorescein isothiocyanate (FITC)-conjugated goat anti-rabbit immunoglobulin $\mathrm{G}(\mathrm{IgG})$, FITCconjugated goat anti-mouse immunoglobulin M (IgM) and affinity purified rabbit anti-laminin IgG from Sigma Inc., St. Louis, MO, USA; tetra-methylrhodamine isothiocyanate (TRITC)-conjugated goat anti-mouse Ig and FITC-conjugated donkey anti-goat IgG from Nordic Immunological Laboratory, Capistrano Beach, CA, USA; affinity purified goat anti-human type IV collagen antibodies from Southern Biotechnology Ass. Inc., Birmingham, AL, USA; affinity purified rabbit anti-human fibronectin IgG from Dako, Glostrup, Denmark. Rabbit anti-basement membrane HSPG and monoclonal mouse anti-HS (JM403) antibody were obtained and characterized as described previously [9, 29].

[35 $]$ GAGs (specific activity $6.10^{5} \mathrm{~Bq} \cdot \mu \mathrm{g}^{-1} \mathrm{GAG}$ ) were obtained from rats injected twice i.p. with $37,000 \mathrm{~Bq}$ $\mathrm{Na}_{2}{ }^{35} \mathrm{SO}_{4} \cdot \mathrm{g}^{-1}$ body weight with a $4 \mathrm{~h}$ time span between each injection. Four hours after the second injection, the rats were sacrificed and the soft tissues (i.e. liver, kidney, intestine etc.) removed. GAGs were extracted by alkaline borohydride.

\section{Animal accommodation}

Animals were accommodated in groups of three and fed ad libitum. For urine collection, animals were accommodated separately in metabolic cages. To avoid stress factors, animals were habituated to these cages for 7 days before treatment.

\section{Induction of pulmonary emphysema}

Male Wistar rats (weight $200 \pm 10$ g) were anaesthetized with $3 \%$ halothane, intubated and artificially ventilated according to MAUDERLY [30]. Rats were hyperventilated, to stop intrinsic breathing for a few seconds, and were instilled during this time span with 0.2 IU pancreatic elastase $\cdot \mathrm{g}^{-1}$ body weight in $0.5 \mathrm{ml}$ saline. Control animals were instilled with $0.5 \mathrm{ml}$ saline. After instillation, rats were ventilated until they awoke.

\section{Histology}

Animals were sacrificed by an overdose of pentobarbital injected i.p. For morphometric studies, lungs were dissected and fixed with $2 \%$ glutaraldehyde in 150 mmol $l^{-1}$ phosphate buffer $(\mathrm{pH} 7.2)$, administered through a polyethylene catheter inserted into the trachea at a pressure of $25 \mathrm{~cm} \mathrm{H}_{2} \mathrm{O}$. After $30 \mathrm{~min}$, lungs were fixed for an additonal $24 \mathrm{~h}$ in $2 \%$ gluteraldehyde, dehydrated and embedded in paraffin. Tissue sections $(6 \mu \mathrm{m})$ were contrasted using the trichrome staining of GOLDNER [31]. To assess the degree of emphysema, the mean linear intercept was determined using a Mop-videoplan image analyser (Kontron $\mathrm{GmbH}$, Eching, München, Germany). Images of tissue sections were projected on a digitization tablet on which a line raster was applied. Of each lung, a total of 400 intercepts, derived from two sections, were measured.
For immunofluorescence studies, lungs were dissected, and inflated through a polyethylene catheter inserted into the trachea with phosphate-buffered saline (PBS) at a pressure of $25 \mathrm{~cm} \mathrm{H}_{2} \mathrm{O}$. PBS-filled lungs were frozen in liquid nitrogen and stored at $-70^{\circ} \mathrm{C}$. Cryosections $(6$ $\mu \mathrm{m})$ were stored at $-70^{\circ} \mathrm{C}$. Cryosections were rehydrated for $10 \mathrm{~min}$ in PBS, containing 1\% BSA. Antibodies were applied for $1.5 \mathrm{~h}$ in PBS containing $1 \% \mathrm{BSA}$. After each antibody, incubation sections were washed in PBS $(3 \times 5 \mathrm{~min})$. Anti-HS antibodies and all secondary antibodies were used at a dilution of 1:100. All other antibodies were used at 1:50. Double staining was performed using fluorescein- and rhodamine-labelled secondary antibodies. Sections were embedded in aquamount and examined on a Zeiss axioskop photomicroscope (Carl Zeiss, Oberkochen, Germany). Observations were made by two blinded observers. A "strong" decrease was defined by large areas in the section showing no specific antibody staining. "Weak" was defined by some small areas in the section which showed a reduced immunostaining. "Moderate" was defined as a moderate number of areas (between strong and weak) showing a clear, but not complete, absence of staining.

\section{Purification of urinary glycosaminoglycans}

Rat urine was collected one day before elastase instillation, then daily for 9 days and finally on Day 19 post instillation. GAGs were purified from urine by anion exchange chromatography. Urine was centrifuged at $2,000 \times \mathrm{g}$ for $10 \mathrm{~min}\left(\right.$ at $4^{\circ} \mathrm{C}$ ), and $20 \mathrm{ml}$ of the supernatant was diluted to $50 \mathrm{ml}$ by adding $10 \mathrm{mmol} \cdot l^{-1}$ Tris- $\mathrm{HCl}(\mathrm{pH} 6.8)$. The diluted samples were loaded onto a column of $5 \times 0.5 \mathrm{~cm}$ containing $0.5 \mathrm{ml}$ DEAE-Sepharose Fast Flow. After an initial wash with $3 \mathrm{ml} 0.2$ $\mathrm{mol} \cdot l^{-1} \mathrm{NaCl} / 10 \mathrm{mmol} \cdot l^{-1}$ Tris-HCl $(\mathrm{pH} 6.8)$, GAGs were eluted with $4 \mathrm{ml} 2 \mathrm{~mol} \cdot l^{-1} \mathrm{NaCl} / 10 \mathrm{mmol} \cdot l^{-1}$ Tris- $\mathrm{HCl}$ ( $\mathrm{pH}$ 6.8). Recovery of GAGs was monitored by adding $9.10^{5}$ $\mathrm{Bq}\left[{ }^{35} \mathrm{~S}\right] \mathrm{GAG}$ to the urine, and was between $72-101 \%$.

\section{Extraction of lung glycosaminoglycans}

GAGs were extracted according to a modified method of Hoffmann [32]. Pleura, large airways and blood vessels were removed. The remaining tissue was defatted in $20 \mathrm{vol}$. acetone at $-20^{\circ} \mathrm{C}$ for $16 \mathrm{~h}$, followed by extraction with $20 \mathrm{vol}$. ether/methanol $(1: 1)$ at $4^{\circ} \mathrm{C}$ for $24 \mathrm{~h}$. The material was dried, pulverized with a glass rod and suspended in $40 \mathrm{vol}$. (w/v) of $0.75 \mathrm{~mol} \cdot l^{-1} \mathrm{NaOH} / 10$ mmol. $l^{-1} \mathrm{NaBH}_{4}$. After $1 \mathrm{~h}$ at $73^{\circ} \mathrm{C}$, the mixture was neutralized with $6 \mathrm{~mol} \cdot l^{-1} \mathrm{HCl}$ and $100 \%(\mathrm{w} / \mathrm{v})$ trichloroacetic acid was added to a final concentration of $6 \%$. After $1 \mathrm{~h}$ at $4^{\circ} \mathrm{C}$, and centrifugation (15 min, 2,000× $\mathrm{g}, 4^{\circ} \mathrm{C}$ ), the pellet was dissolved in $0.1 \mathrm{~mol} \cdot l^{-1} \mathrm{NaOH}$. The protein concentration was determined according to Lowry et al. [33]. To the supernatant, 5 vol. of ethanol $(100 \%)$ was added and after $16 \mathrm{~h}$ at $-20^{\circ} \mathrm{C}$ the mixture was centrifuged $\left(30 \mathrm{~min}, 15,000 \times \mathrm{g}, 4^{\circ} \mathrm{C}\right)$. The precipitated GAGs were dried and dissolved in demineralized water. GAGs were quantified using the 1,9dimethylmethylene blue (DMMB) assay (see below). 
Quantification of sulphated glycosaminoglycans

The content of sulphated GAGs was determined using the DMMB assay of FARNDALE and co-workers [34, 35]. To $100 \mu \mathrm{l}$ sample (urine or lung extract) $2.5 \mathrm{ml}$ of DMMB reagent was added and the absorbance at $525 \mathrm{~nm}$ was measured directly. The DMMB reagent consists of 48 $\mu \mathrm{mol} \cdot l^{-1} \mathrm{DMMB}$ (initially $48 \mu \mathrm{mol} \mathrm{DMMB}$ was dissolved in $5 \mathrm{ml} 96 \%$ ethanol), $42 \mathrm{mmol} \cdot l^{-1}$ glycine and 42 mmol $\cdot l^{-1} \mathrm{NaCl}$, adjusted to $\mathrm{pH} 3.0$ with $1 \mathrm{~mol} \cdot l^{-1} \mathrm{HCl}$. Chondroitin 4-sulphate was taken as a standard and included within each series of assays. For calculations we used second order regression analysis.

\section{Quantification of urinary heparan sulphate content}

Urinary HS content was determined by a nonequilibrium inhibition enzyme-linked immunosorbent assay (ELISA). To $100 \mu \mathrm{l}$ sample $100 \mu \mathrm{l}$ anti-HS (JM403) (dilution $1 / 40,000$ in Tris-buffered saline ( $\mathrm{pH} 7.2)$ containing $0.1 \%$ Tween-20 (TBST) and $1 \%$ BSA) was added. After $16 \mathrm{~h}$ at $4^{\circ} \mathrm{C}, 100 \mu \mathrm{l}$ of this mixture was transferred to a HS-coated microtitre plate, and free anti-HS antibodies were allowed to bind to the coated HS for $2 \mathrm{~h}$. The plate was washed with TBST and $100 \mu$ l alkaline phosphatase conjugated anti-mouse $\mathrm{Ig}$, at a dilution of
1/2,000 in TBST/BSA was added. After $1 \mathrm{~h}$, the plates were washed with TBST and alkaline phosphatase was detected using $1 \mathrm{mg} \cdot \mathrm{ml}^{-1}$ dinitrophenyl phosphate in 1 mol $\cdot l^{-1}$ diethanolamine ( $\mathrm{pH}$ 9.8) containing $50 \mathrm{mmol} \cdot l^{-1}$ $\mathrm{MgCl}_{2}$. Absorbance was measured at $405 \mathrm{~nm}$. Bovine kidney HS was taken as a standard within each series of assays.

\section{Characterization of urinary glycosaminoglycans}

Purified urinary GAGs were separated on agarose gel using $0.1 \mathrm{~mol} \cdot l^{-1}$ barium acetate ( $\mathrm{pH} 5.0$ ) as electrophoresis buffer. GAGs were visualized using a combined azure A silver-staining [36].

\section{Creatinine assay}

Creatinine was measured using the alkaline picrate method, based on the Jaffé reaction (Sigma, procedure No. 555).

\section{Statistical analysis}

Intergroup comparison was calculated using Student's t-test. Correlation analysis was performed using Pearson's product moment correlation test [37]. All values are given as mean \pm SEM. Data were normally distributed.
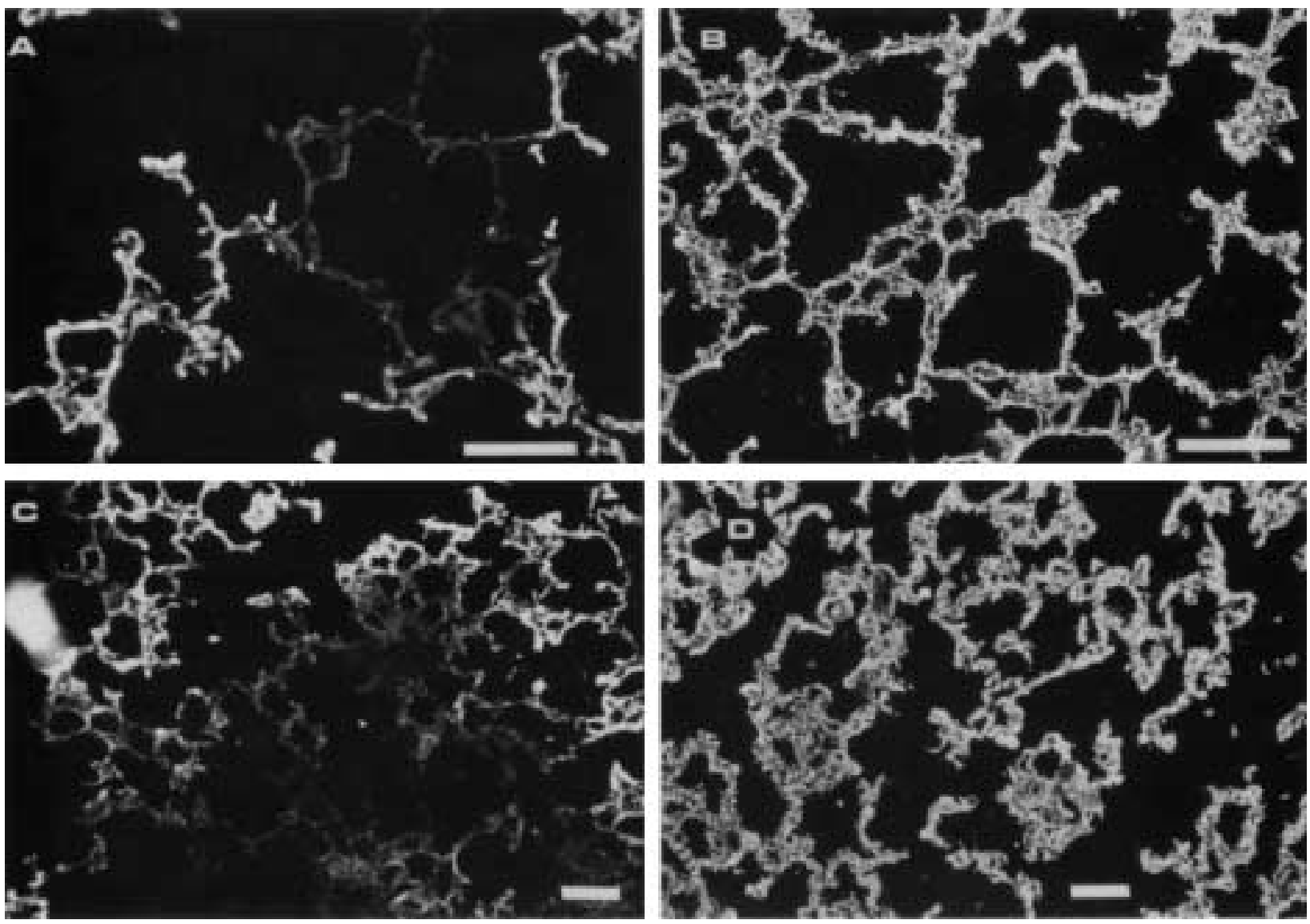

Fig. 1. - Immunofluorescence of lung tissue stained with anti-heparan sulphate (HS) antibodies $3 \mathrm{~h}$ after treatment of rats with elastase: A) detail and C) overview; or saline: B) detail and D) overview. Note the abrupt changes in immunostaining (see arrows). (Internal scale bar $=100 \mu \mathrm{m})$. 

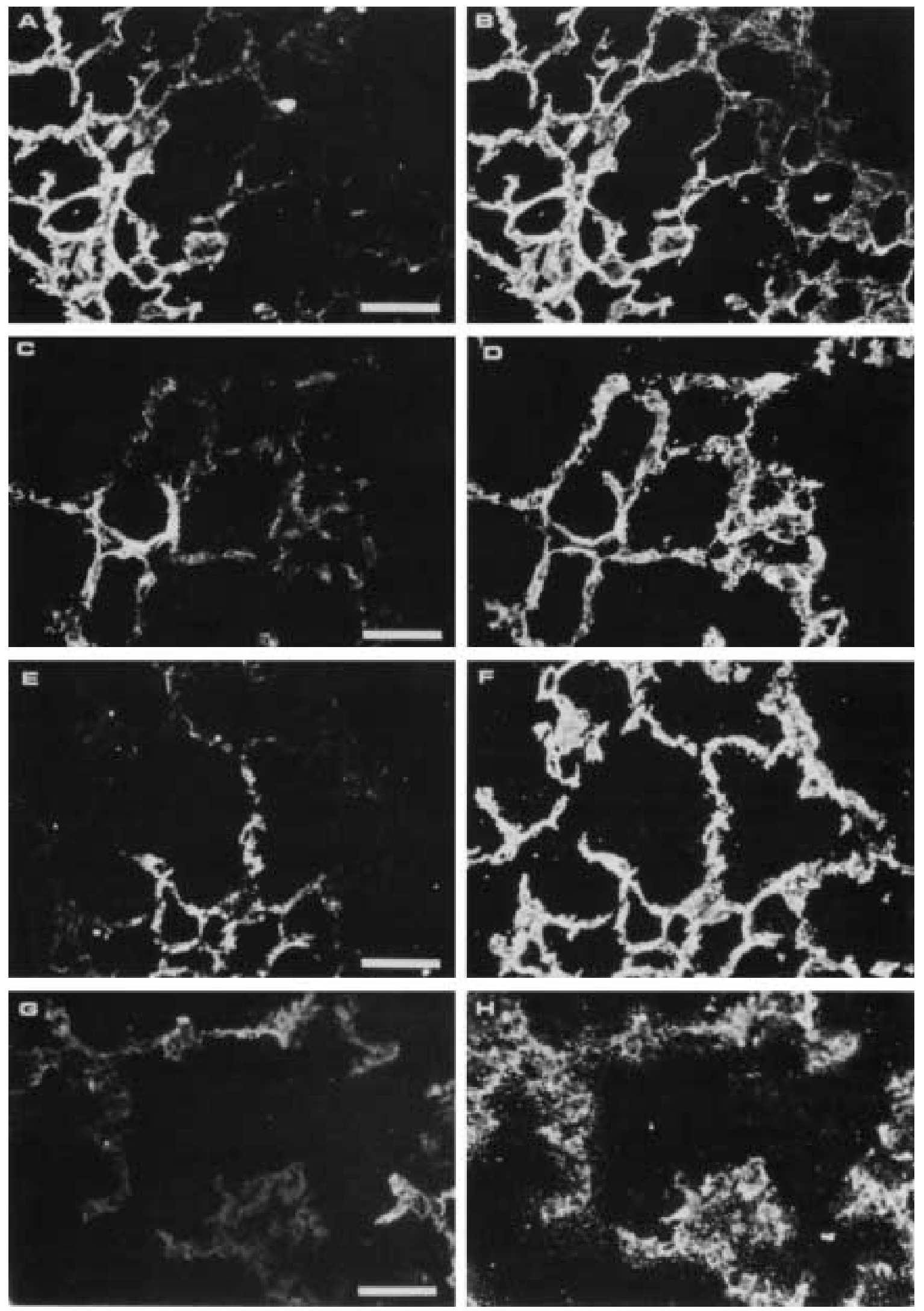

Fig. 2. - Immunofluorescence double staining of rat lung tissue 1 day after elastase treatment. Panels A, C, E and G show staining for heparan sulphate (HS) and panels B, D, F and H staining for heparan sulphate proteoglycan (HSPG) core-protein, type IV collagen, laminin and fibronectin, respectively. Note that only staining for HS and HSPG is reduced or absent compared to lung of saline-treated rats (see fig. 1 for HS). (Internal scale bar $=100 \mu \mathrm{m})$. 
Table 1. - Effects of elastase treatment on immunostaining of alveolar basement membrane components

\begin{tabular}{lcccccc}
\hline \multicolumn{7}{c}{ Time after elastase treatment } \\
& $3 \mathrm{~h}$ & $1 \mathrm{~d}$ & $2 \mathrm{~d}$ & $3 \mathrm{~d}$ & $5 \mathrm{~d}$ & $7 \mathrm{~d}$ \\
\hline HS & $\downarrow \downarrow \downarrow$ & $\downarrow \downarrow \downarrow$ & $\downarrow \downarrow \downarrow$ & $\downarrow \downarrow$ & $\downarrow$ & $\downarrow$ \\
HSPG & $\downarrow \downarrow$ & $\downarrow \downarrow$ & $\downarrow$ & $\downarrow$ & - & - \\
$\begin{array}{l}\text { core protein) } \\
\text { Laminin }\end{array}$ & - & - & - & ND & ND & ND \\
$\begin{array}{l}\text { Fibronectin } \\
\text { Type IV }\end{array}$ & - & - & - & ND & ND & ND \\
collagen & - & - & - & ND & ND & ND \\
\hline
\end{tabular}

HS: heparan sulphate; HSPG: heparan sulphate proteoglycan; ND: not determined; -: no effect; $\downarrow$ : weak decrease; $\downarrow \downarrow$ : moderate decrease; $\downarrow \downarrow \downarrow$ : strong decrease.

\section{Results}

\section{General histology}

Three hours after intratracheal instillation of porcine pancreatic elastase, we observed an infiltration of inflammatory cells into the lung accompanied by haemorrhages and pulmonary oedema, indicating acute lung injury. This stage persisted for about 3 days. Lung morphology returned to normal after 5-7 days. Two weeks after elastase treatment the first emphysematous lesions could be observed. Forty days after elastase treatment the mean linear intercept was increased to $81.7 \pm 2.3 \mu \mathrm{m}$ $(\mathrm{n}=17)$, compared to $58.6 \pm 1.2 \mu \mathrm{m}(\mathrm{n}=8)$ for controls.

\section{Immunofluorescence studies of basement membrane com- ponents}

In lung parenchyma, HS is linearly distributed in alveoli in accordance with its presence in basement membranes (fig. 1). Table 1 summarizes the effects of elastase on basement membrane components. Three hours after elastase treatment, large areas of the lung lacked HS staining (fig. 1A and C). In some cases, one alveolus was completely devoid of HS, whilst in the adjacent alveolus staining was normal (fig. 1A). At places where HS staining was reduced or absent, staining for the core protein of HSPG was also reduced, although to a lesser extent (fig. 2A and B). After 5 days, most HS staining had returned. At all times, staining for type IV collagen, laminin and fibronectin was normal, even at places where HS staining was absent (fig. $2 \mathrm{C}-\mathrm{H}$ ). Attempts to localize elastase using commercial antibodies were unsuccessful. The elastase used was devoid of HS digesting activity, as was demonstrated by incubation of HS with elastase followed by assaying the molecular mass of HS by polyacrylamide gel electrophoresis (data not shown).

\section{Lung and urinary GAG content after elastase instillation}

During the first 3 days after elastase treatment, the con-

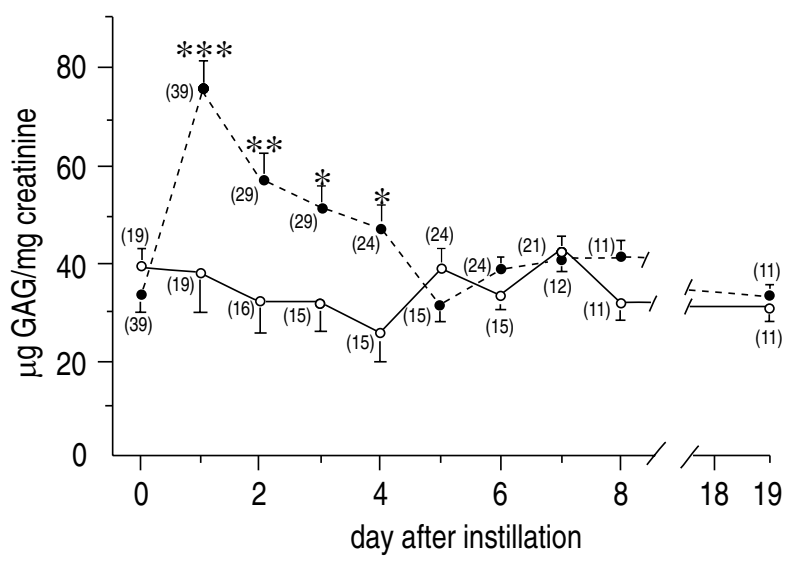

Fig. 3. - Urinary glycosaminoglycan (GAG) content after intratracheal elastase instillation. O: saline-treated rats; ๑: elastase-treated rats. *: $\mathrm{p}<0.01 ; * *: \mathrm{p}<0.005 ; * * *: \mathrm{p}<0.0005$. Numbers of rats are indicated in brackets.

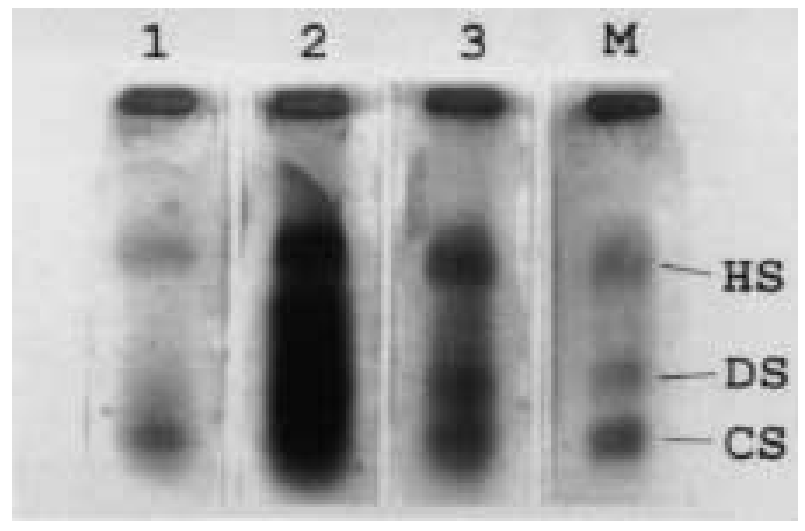

Fig. 4. - Separation of diethylaminoethyl (DEAE)-purified urinary glycosaminoglycans (GAGs) of an individual rat by agarose gel electrophoresis. Lane 1: 1 day before; lanes 2 and 3: 1 and 3 days after elastase treatment, respectively; M: marker GAGs; HS: heparan sulphate; DS: dermatan sulphate; CS: chondriotin sulphate. The amounts of urinary GAGs applied to the gel were derived from urine samples, containing $1.25 \mu \mathrm{g}$ creatinine. Note the increase of HS and DS after elastase treatment (lanes 2 and 3 ).

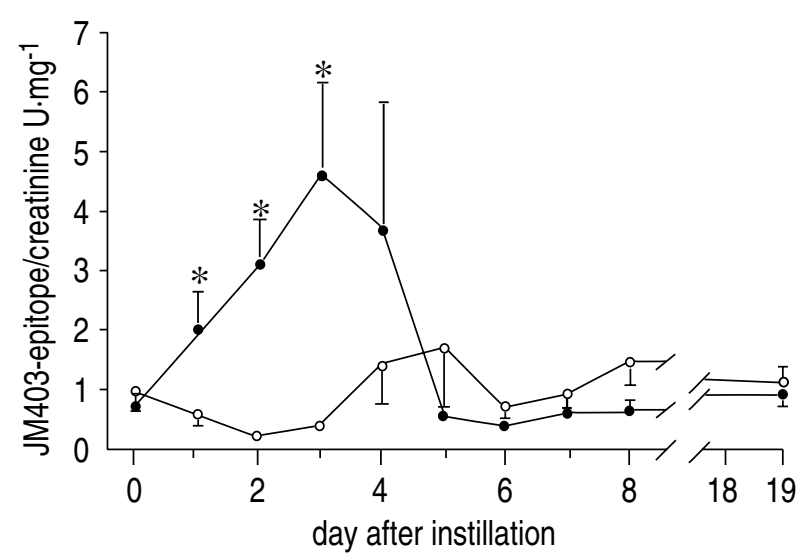

Fig. 5. - Urinary heparan sulphate (HS-epitope JM403) content after intratracheal elastase instillation. $\bigcirc$ : saline-treated rats; $\bullet$ : elastasetreated rats $(n=6)$. *: $\mathrm{p}<0.01$. HS content was determined by an enzyme-linked immunosorbent assay (ELISA) using bovine kidney HS as a standard. Note that the unit HS-epitope JM403. $\mathrm{mg}^{-1}$ creatinine is arbitrary; it reflects the amount of the HS-epitope JM403 corresponding to $1 \mu \mathrm{g}$ bovine kidney HS. 


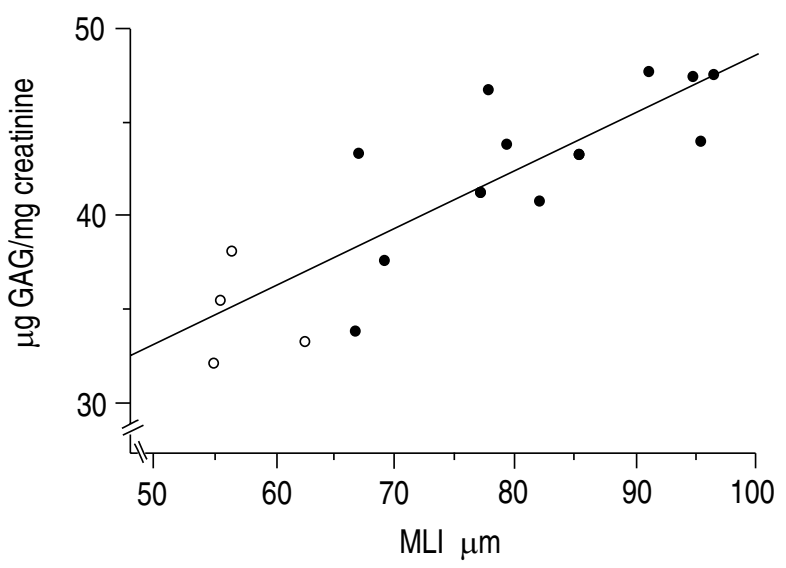

Fig. 6. - Correlation of the mean linear intercept (MLI) measured 40 days after treatment and the urinary GAG excretion during the first 4 days after treatment $(\mathrm{p}<0.0001 ; \mathrm{r}=0.85)$. $\mathrm{O}$ : saline-treated rats; elastase-treated rats.

tent of GAGs in lung tissue was significantly decreased $\left(2.8 \pm 0.07(\mathrm{n}=8)\right.$ versus $4.6 \pm 0.2(\mathrm{n}=8) \mu \mathrm{g} \mathrm{GAG} \cdot \mathrm{mg}^{-1}$ protein, for saline-treated rats $(\mathrm{p}<0.0001))$. Thereafter, no significant changes could be observed.

The concentration of GAGs in urine was significantly increased during the first 4 days after elastase treatment, with a maximum at Day 1 (fig. 3). Agarose gel electrophoresis of the GAGs shows that in addition to the HS the DS excretion was also markedly increased after elastase treatment, with a maximum at Day 1 (fig. 4). ELISA of purified urinary GAGs displayed a significant increase in HS (JM403 epitope) 1-3 days after elastase treatment, with a maximum level at Day 3 (fig. 5). The apparent discrepancy between the day of peak level of HS measured by ELISA and of HS determined by agarose electrophoresis may be explained by the specificity of the JM403 antibody. This antibody recognizes only HS from basement membranes and not HS from other sources, such as those located at the cell surface [29], which are probably also removed from the alveoli as a result of elastase treatment. Therefore, perhaps the HS at Day 1 (lane 2, fig. 4) consisted mainly of nonbasement HS, not detected by the JM403 antibody. This, however, requires further study.

The extent of emphysema, measured as the increase of mean linear intercept 40 days after induction, was positively correlated to the concentration of GAGs in the urine during the first 4 days after induction (the time at which GAG excretion was increased) (fig. 6).

\section{Discussion}

The predominant theory on the pathogenesis of emphysema emanates from a disturbance of the protease/ antiprotease balance, favouring the proteases [10-12]. Elastin has been regarded as the target molecule in the extracellular matrix. In pancreatic elastase-induced emphysema, elastin breakdown occurs [38]. Elastase, however, is an indiscriminate enzyme, capable of the in vitro degradation of many proteins, including proteoglycans, collagen, fibronectin and laminin. Little is known about the in vivo effect of elastase on these molecules. In this study, we have shown that, in particular, proteoglycans are target molecules for instilled elastase in rat lungs. Fibronectin, type IV collagen and laminin were not affected, although small changes may have gone undetected using immunohistochemistry. These results are in accordance with an electron microscopical study on pancreatic elastase-induced emphysema showing no change in laminin or appearance of the basement membrane, but elimination of HS [39, 40]. The observation that in places where HS staining is absent staining for HSPG core protein is only reduced, can be explained by incomplete cleavage of the HSPG core protein. Since all three HS chains are attached to the N-terminus of the protein $[41,42]$, one cut at this end of the protein will release all HS chains, whereas a large part of the core protein, and thus most of the epitopes for the polyclonal anti-HSPG antibodies, remain present in the basement membrane.

It has been postulated that proteases can induce emphysematous lesions only if they possess elastolytic activity [43]. However, several animal models for emphysema exist where there is no elastin breakdown, including emphysema induced by $\mathrm{CdCl}_{2}[44,45]$, by $90 \%$ oxygen [46], or by collagenase [47], and genetic emphysema in the tight-skin mouse [48]. In addition, leucocyte elastase, implicated in emphysematogenesis in man, has been reported to lack elastolytic activity [49]. There is no consensus on elastin breakdown in human pulmonary emphysema [50-52]. We suggest, as an alternative possibility, that degradation of proteoglycans (e.g. by leucocyte elastase) is associated with the onset of the disease.

Proteoglycans are implicated in a number of functions important for the integrity of the extracellular matrix, which is compromised in emphysema. The GAGs are powerful inhibitors of proteases, including leucocyte elastase [20, 22, 53], and prevent leucocyte elastaseinduced emphysema in mouse and rat $[23,24]$. Ultrastructurally, proteoglycans are present around collagen fibrils, elastin fibres and in basement membranes $[6,25$, $27,28]$. Removal of proteoglycans associated with elastin facilitates the digestion of the latter [54-56]. In addition, proteoglycans are involved in the fibrillogenesis of the major fibrillar components, collagen and elastin, and may influence their mechanical characteristics [3, 4, 57]. Proteoglycans, especially HSPGs, bind and modulate growth factors, including basic fibroblast growth factor bFGF), interferon- $\gamma$, interleukin- 8 and transforming growth factor- $\beta$ [16-20]. In lung parenchyma, degradation of HS by heparitinase results in the release of bFGF [58]. Hence, removal of proteoglycans from the alveolar wall, e.g. by proteolysis, may result in a disturbance of the extracellular matrix, which may ultimately lead to emphysematous lesions. Intratracheal instillation of hyaluronidase (which digests some types of GAG) together with $60 \%$ oxygen results in airspace enlargement after 4 days [59]. 
The disappearance of HSPG in the lung is accompanied by an increase of GAGs in the urine. This increase, observed during the first 4 days after elastase instillation, is positively correlated with the increase of the mean linear intercept, an indicator for parenchymal destruction, 40 days after instillation. Increase of urinary GAGs may, therefore, be an indicator for tissue destruction and may be of value in predicting the long-term outcome of acute tissue destruction (e.g. during exacerbations).

In conclusion, intratracheal instillation of pancreatic elastase in rats results in digestion of proteoglycans but not of other basement membrane components. The concomitant increase in urinary GAGs is positively correlated with the degree of emphysematous lesions observed after 40 days. The vulnerability of PGs toward proteases may be of importance in the pathogenesis of emphyema.

Acknowledgements: The authors thank L. van den Heuvel (Dept of Biochemistry, University of Nijmegen) and J. van den Born (Dept of Nephrology, University of Nijmegen) for the polyclonal antibody directed against HSPG and the monoclonal antibody against HS, respectively.

\section{References}

1. Crystal RG, Ferrans VJ, Basset F. Biologic basis of pulmonary fibrosis. In: Crystal RG, West JB, eds. The Lung: Scientific Foundations. New York, Raven Press Ltd, 1991.

2. Lucey EC, Stone PJ, Snider GL. Consequences of proteolytic injury. In: Crystal RG, West JB, eds. The Lung: Scientific Foundations. New York, Raven Press Ltd, 1991.

3. Danielsen CC. Mechanical properties of reconstituted collagen fibrils. Conn Tissue Res 1982; 9: 219-225.

4. Vogel KG, Paulsson M, Heingard D. Specific inhibition of type I and II collagen fibrillogenesis by the small proteoglycans of tendon. Biochem J 1984; 223: 587-597.

5. Scott JE, Orford CR. Dermatan sulphate rich proteoglycans associated with rat tail-tendon collagen at the D-band in the gap region. Biochem J 1981; 197: 213-216.

6. Van Kuppevelt THMSM, Cremers FPM, Domen JGW, van Beuningen HM, van den Brule AJC, Kuyper CMA. Ultrastructural localization and characterization of proteoglycans in human lung alveoli. Eur J Cell Biol 1985; 36: 74-80.

7. Timpl R. Proteoglycans of basement membranes. Experientia 1993; 49: 417-428.

8. Gallagher JT, Lyon M, Steward WP. Structure and function of heparan sulfate proteoglycans. Biochem J 1986; 236: 313-325.

9. Van den Heuvel LPWJ, van den Born J, van de Velden TJAM, Veerkamp JH, Monnens LAH, Berden JHM. Isolation and partial characterization of heparan sulfate proteoglycan from the human glomerular basement membrane. Biochem J 1989; 264: 457-465.

10. Gadek JE, Pacht ER. The protease-antiprotease balance within the human lung: implications for the pathogenesis of emphysema. Lung 1990; Suppl. 168: 552-564.

11. Weissler JC. Pulmonary emphysema: current concepts of pathogenesis. Am J Med Sci 1987; 293: 125-138.

12. Snider GL. Emphysema - the first two centuries - and beyond: a historical overview, with suggestions for future research. 2. Am Rev Respir Dis 1992; 146: 16151622.

13. Gadek JE, Fells GA, Zimmerman RL, Crystal RG. Role of connective tissue proteases in the pathogenesis of chronic inflammatory lung disease. Environ Health Perspect 1984; 55: 297-306.

14. Kittelberger R, Neale TJ, Francky KT, Greenhill NS, Gibson GJ. Cleavage of type VIII collagen by human neutrophil elastase. Biochem Biophys Acta 1992; 1139: 295-299.

15. Heremans A, De Cock B, Cassiman JJ, van den Berghe H, David G. The core protein of the matrix-associated heparan sulfate proteoglycan binds to fibronectin. $J$ Biol Chem 1990; 265: 8716-8724.

16. Kjellen L, Lindahl U. Proteoglycans: structures and interactions. Апnи Rev Biochem 1991; 60: 443-475.

17. Yamaguchi Y, Mann DM, Ruoslahti E. Negative regulation of transforming growth factor- $\beta$ by the proteoglycan decorin. Nature 1990; 346: 281-284.

18. Border WA, Noble NA, Yamamoto T, et al. Natural inhibitor of transforming growth factor-beta protects against scarring in experimental kidney disease. Nature 1992; 360: 361-364.

19. Lortatjacob H, Grimaud JA. Interferon-gamma binds to heparan sulfate by a cluster of amino acids located in the C-terminal part of the molecule. FEBS Lett 1991; 280: $152-154$.

20. Webb LMC, Ehrengruber MU, Clarklewis I, Baggiolini $\mathrm{M}$, Rot A. Binding to heparan sulfate or heparan enhances neutrophil responses to interleukin-8. Proc Natl Acad Sci USA 1993; 90: 7158-7162.

21. Yanagishita M. Function of proteoglycans in the extracellular matrix. Acta Pathol Jpn 1993; 43: 283-293.

22. Walsh RL, Dillon TJ, Scicchitano R, Mclennan G. Heparan and heparan sulphate are inhibitors of human leucocyte elastase. Clin Sci 1991; 81: 341-346.

23. Rao NV, Kennedy TP, Rao G, Ky N, Hoinal JR. Sulfated polysaccharides prevent human leucocyte elastaseinduced acute lung injury and emphysema in hamsters. Am Rev Respir Dis 1990; 142: 407-412.

24. Lafuma C, Frisdal E, Harf A, Robert L, Hornebeck W. Prevention of leucocyte elastase-induced emphysema in mice by heparin fragments. Eur Respir J 1991; 4: 1004-1009.

25. Van Kuppevelt THMSM, Domen JGW, Cremers FPM, Kuyper CMA. Staining of proteoglycans in mouse lung alveolar. I. Ultrastructural localization of anionic sites. Histochem J 1984; 16: 657-669.

26. Rutten TLM, van Kuppevelt THMSM, Kuyper CMA, Jansen HMJ. Ultrastructural localization of a chondroitinase-sensitive, cuprolinic blue-positive filament in developing mouse lung. Eur J Cell Biol 1987: 45: 256261.

27. Van Kuppevelt THMSM, Cremers FPM, Domen JGW, Kuyper CMA. Staining of proteoglycans in mouse lung alveoli. II. Characterization of the cuprolinic bluepositive, anionic sites. Histochem J 1984; 16: 671-686.

28. Sannes PL. Cytochemical visualization of anions in collagenous and elastic fibre-associated connective tissue matrix in neonatal and adult rat lungs using iron-containing stains. Histochemistry 1986; 84: 49-56.

29. Van den Born J, van den Heuvel LPWJ, Bakker MAH, Veerkamp JH, Assmann KJM, Berden JHM. A monoclonal antibody against GBM heparan sulfate induces an acute selective proteinuria in rats. Kidney Int 1992; 41: $115-123$.

30. Mauderly JL. Bronchopulmonary lavage of small laboratory animals. Lab Animal Sci 1977; 27(2): 255-261. 
31. Goldner J. A modification of the Masson trichrome technique for routine laboratory purposes. Am J Pathol 1938; 14: 237.

32. Hoffman P. The chemistry of the protein-polysaccharides of connective tissue. In: Quintarelli $\mathrm{G}$, ed. The Chemical Physiology of Mucopolysaccharides. London, J. \& A. Churchill Ltd, 1968; pp. 39-49.

33. Lowry OH, Rosenbrough NJ, Farr AL, Randall RJ. Protein measurement with the folin phenol reagent. J Biol Chem 1951; 193: 265-275.

34. Farndale RW, Buttle DJ, Barrett AJ. Improved quantitation and discrimination of sulfated glycosaminoglycans by use of dimethylmethylene blue. Biochem Biophys Acta 1986; 883: 173-177.

35. Farndale RW, Sayers CA, Barrett AJ. A direct spectrophotometric microassay for sulfated glycosaminoglycans in cartilage cultures. Conn Tissue Res 1982; 9: $247-$ 248.

36. Van de Lest CHA, Versteeg EMM, Veerkamp JH, Van Kuppevelt TH. Quantification and characterization of glycosaminoglycans at the nanogram level by a combined azure A-silver staining in agarose gels. Anal Biochem 1994; 221: 356-361.

37. Kirkwood BR. Essentials of Medical Statistics. Oxford, Blackwell Scientific Publications, 1989.

38. Morris SM, Kagan HM, Stone PJ, Snider GL, Albright JT. Ultrastructural changes in hamster lung 15 minutes to 3 hours after exposure to elastase. Anat Rec 1986; 215: 134-143

39. Vaccaro CA, Wu Z, Hinds A, Snider GL, Brody JS. Altered basement membrane proteoglycans in pancreatic elastase-induced emphysema. Am Rev Respir Dis 1985; Suppl. A387, 131 (Abstract)

40. Crouch EC, Martin GR, Brody JS. Basement membranes. In: Crystal RG, West JB, eds. The Lung: Scientific Foundations. New York, Raven Press Ltd, 1991 pp. 421437.

41. Noonan DM, Fulle A, Valente P, et al. The complete sequence of perlecan, a basement membrane heparan sulfate proteoglycan, reveals extensive similarity with laminin-A chain, low density lipoprotein-receptor, and the neural cell adhesion molecule. J Biol Chem 1991; 266: 22939-22947.

42. Kallunki P, Tryggvason K. Human basement membrane heparan sulfate proteoglycan core protein-A $467 \mathrm{KD}$ protein containing multiple domains resembling elements of the low density lipoprotein receptor, laminin, neural cell adhesion molecules, and epidermal growth factor. J Cell Biol 1992; 116: 559-571.

43. Sloan B, Abrams WR, Meranze DR, Kimbel P, Weinbaum G. Emphysema induced in vitro and in vivo in dogs by a purified elastase from homologous leucocytes. Am Rev Respir Dis 1981; 124: 295-301.

44. Hoidal JR, Niewoehner DE, Rao NV, Hibbs MS. The role of neutrophils in the development of cadmium chloride-induced emphysema in lathyrogen-fed hamsters. Am J Pathol 1985; 120: 22-29.

45. Snider GL, Lucey EC, Faris B, Jung Legg Y, Stone PJ, Franzblau C. Cadmium chloride-induced airspace enlarge- ment with interstitial pulmonary fibrosis is not associated with destruction of lung elastin: implications for the pathogenesis of human emphysema. Am Rev Respir Dis 1988; 137: 918-923.

46. Riley DJ, Kramer MJ, Kerr JS, Chae CU, Yu SY, Berg RA. Damage and repair of lung connective tissue in rats exposed to toxic levels of oxygen. Am Rev Respir Dis 1987; 135: 441-447.

47. Darmiento J, Dalal SS, Okada Y, Berg RA, Chada K. Collagenase expression in the lungs of transgenic mice causes pulmonary emphysema. Cell 1992; 71: 955-961.

48. Starcher B, James H. Evidence that genetic emphysema in tight-skin mice is not caused by neutrophil elastase. Am Rev Respir Dis 1991; 143: 1365-1368.

49. Aoki Y, Yamazakihase T. Both medullasin and human leukocyte elastase are essentially devoid of elastinolytic activity. J Biochem Tokyo 1993; 114: 122-125.

50. Niewoehner DE, Kleinerman J. Morphometric study of elastic fibres in normal and emphysematous human lungs. Am Rev Respir Dis 1977; 115: 15-21.

51. Frette C, Wei SM, Neukirch F, et al. Relation of serum elastin peptide concentration to age, $\mathrm{FEV}_{1}$, smoking habits, alcohol consumption, and protease inhibitor phenotype: an epidemiological study in working men. Thorax 1992; 47: 937-942.

52. Pelham F, Wewers M, Crystal R, Janoff A. Urinary desmosine excretion is normal in patients with homozygous alpha ${ }_{1}$-antitrypsin deficiency. Am Rev Respir Dis 1984; 129: 307.

53. Redini F, Lafuma C, Hornebeck W, Choay J, Robert L. Influence of heparin fragments on the biological activities of elastase(s) and alpha 1 -proteinase inhibitor. Biochem Pharmacol 1988; 37: 4257-4261.

54. Stone PJ, McMahon MP, Morris SM, Calore JD, Franzblau C. Elastin in a neonatal rat smooth muscle cell culture has greatly decreased susceptibility to proteolysis by human neutrophil elastase: an in vitro model of elastolytic injury. In Vitro Cell Dev Biol 1987: 23: 663-676.

55. Stone PJ. Perspective degradation of extracellular matrix proteoglycans by human neutrophils. Am J Respir Cell Mol Biol 1990; 2: 491-492.

56. Werb Z, Banda J, Jones PA. Degradation of connective tissue matrices by macrophages. I. Proteolysis of elastin, glycoproteins, and collagen by proteinases isolated from macrophages. J Exp Med 1980; 152: 1340-1357.

57. McGowan SE, Liu RG, Harvey CS. Effects of heparin and other glycosaminoglycans on elastin production by cultured neonatal rat lung fibroblasts. Arch Biochem Biophys 1993; 302: 322-331.

58. Sannes PL, Burch KK, Khosla J. Immunohistochemical localization of epidermal growth factor and acidic and basic fibroblast growth factors in postnatal developing and adult rat lungs. Am J Respir Cell Mol Biol 1992; 7: 230-237.

59. Cantor JO, Cerreta JM, Armand G, Keller S, Turino GM. Pulmonary airspace enlargement induced by intratracheal instillment of hyaluronidase and concomitant exposure to 60 percent oxygen. Exp Lung Res 1993; 19: 177-192. 